\title{
Does Instagram as Learning Media Affect Students' Writing Skill on Recount Text?: An Experimental Research
}

\author{
Ismi Baqiatus Sallamah \& Agus Husein As Sabiq \\ IAIN Purwokerto, Indonesia \\ ismibaqia01@gmail.com
}

\begin{abstract}
Received : 2020-11-18
Revised : 2020-12-03

Accepted : 2020-12-23
\end{abstract}

ARTICLE HISTORY

\section{KEYWORDS}

Instagram

Learning Media

Recount Text

Writing

\begin{abstract}
This research's objectives were to examine whether Instagram as a Learning Media is useful toward students' writing recount text or not and measuring how significant the effect of Instagram on students' writing recount text before and after treatment. This quasi-experimental research involved 35 students as participants from two different classes. Researchers took $10^{\text {th }}$ graders from a selected private school in Purbalingga as research samples. Two IPS classes were selected, i.e., X IPS 1 was set as an experimental class, and X IPS 2 was set as a control class. The data were collected from the score of pre-test and post-test after the treatment. Researchers then compared the students' achievement from control and experimental classes and analyzed the data using descriptive analysis and $\mathrm{N}$-gain. The research findings indicated a significant achievement of students' competencies in using Instagram than conventional learning in writing recount text. The average N-gain score from experimental class and control class obtained $0.308>0.057$. The Mean score of pre-test in experimental and control class obtained $69.875>64.818$ and the Mean score of post-test in experimental and control class was $79.461>67.142$. As a result, the experimental class's mean score was higher than the control class means Instagram as a Learning Media is useful in writing recount text.
\end{abstract}

\section{Introduction}

Generally, someone should learn four skills to learn a language. There are integrated skills to learn in English, such as speaking, reading, listening and writing. Writing is one of the main competencies that students should master. Writing is a thinking method that requires a great deal of work to rearrange concepts and feelings (Linse \& Nunan, 2005). They need to convey their feelings in writing in the right way. They need to communicate their ideas and feelings creatively so that the reader can understand their writing. Writing has a unique role in language teaching, as its acquisition requires the practice and understanding of three other language skills, such as listening, reading and speaking (Klimova, 2012).

The composition of the digital age of education is one of the hurdles in teaching. Students appear to have access to their social media platform regularly. They also speak to their friends, update their social networks, and share their images to be up-to-date. The phenomenon of using social media is essential to use the learning media network in the teaching and learning process of writing classes (Ismail et al., 2018; Salikin \& Tahir, 2017). Several approaches can be applied to writing teaching in the classroom. One of the approaches in which it has recently been implemented is a discourse and genre-based approach.

The discourse and genre approach is related to how writing is taught for unique purposes and contexts (Dirgeyasa, 2016; Richards, 2015).
Discourse and rhetorical theories of the genre are concerned with the ways actors use language to take on social identities and mediate situations (Collin, 2012). It shows that students need to compose their text that suits the intent and meaning of writing themes. Thus, effective teaching is mainly required for learners who use English as a foreign language, especially in the media. Effective media are required to make students more interested in learning English.

Current technology is rising very rapidly, and technological innovations in Indonesia, especially in the education sector. The use of technology in education is one indicator that will help students improve their skills and learn (Gunantar \& Transinata, 2019). Among the students' popularity, Instagram offers an excellent opportunity for the teacher to design a creative learning activity. Instagram helps students develop ideas and provide a learning experience that they enjoy, with contextual content (Basith, 2020; F. Handayani, 2016). As one of the social media sites, Instagram is commonly used by students. It offers users an instant way to capture and share their life moments with friends through a series of (filter manipulated) images and videos ( $\mathrm{Hu}$ et al., 2014).

Instagram is a mobile photo-sharing application that allows users to take photos, use filters, and post them on the site itself. Instagram has more than 400 million active monthly users who post more than 40 billion photos (Alhabash \& Ma, 2017). Instagram may take up several functions: creating accounts, posting 
content, applying filters, adding subtitles, Tag User, adding locations, adding hashtags, including content, adding comments, navigating and tracking other accounts, checking the following accounts for feeds, and exploring hashtags/users (search for) (Al-Ali, 2014). On Instagram, users can express feelings and situations where they are. Instagram is a media to upload and share photos with fellow Instagram users. Instagram users can communicate by commenting on photos. As a result, Instagram seems to provide a perfect atmosphere for L2 learners to create descriptive or recount writing.

Many things can be achieved using Instagram. By writing skills, students could write text to the "caption" section, and the student could provide input in a comment column before sharing their images or videos. That will be more fun for students than writing a paper. This tool helps students to share views and perspectives on various topics. Students may also participate in a group event where everyone asks each student to comment on a photo or a video. It helps them to share information with students and teachers.

Some researchers investigated students' perception of the use of Instagram in writing teaching. Students were reported to have a positive perception of the use of Instagram as a learning media. Instagram offers enjoyable classroom environments and encourages students to be innovative, communicative and often collaborative with peers (Anggraeni, 2017; Damayanti \& Santoso, 2019; Gunantar \& Transinata, 2019; Mr \& Seftika, 2019). Distinguished with this research, the researchers used experimental research to examine whether Instagram is useful or not in teaching writing. Another research is conducted by Shazali et al. (2019) who employed a classroom action research to explore Instagram as a learning tool in developing students' English language writing ability. The study's findings indicated that Instagram is a useful tool for developing vocabulary and grammatical accuracy for learners. With the similarity of using Instagram, this research focused on one of the productive writing skills.

In this study, the researchers proposed Instagram as a tool for teaching writing. Instagram is versatile and can be used as a learning medium. Instagram can be accessed anywhere, and at any time, Instagram can also be accessed via mobile phone and device. Instagram helps students to display and say what they are going to chat. Students should show some of the images and post them on Instagram so that the others can see. Instagram can be a meaningful environment for developing student writing skills, especially in writing recount texts. Through the feature of photo sharing on Instagram, for example, the students can post their images publicly to retell the past events they have experienced. Besides, this feature allows them to interact with their peers, instructor, and other viewers by discussing the picture description's content. The shared images can be posted in a series so that they can represent the series of events. If any students can post a new post on Instagram for a day, it would be meaningful to develop their language if they write their post in English to write in English.

With the features inside Instagram, the teachers can consider this kind of social media to be meaningful instructional media. Its popularity among the young generation and characteristics to share images can help the students develop their writing skills, both personal and factual recount text. Therefore, this research aimed to examine whether Instagram as a Learning Media is useful toward students' writing recount text or not and to measure how far the significant effect of Instagram on students' writing recount text before and after treatment.

\section{Method}

In this research, the researchers used experimental research with two groups becoming the subject of the research. The experimental treatment is defined as the experimental group, and the other which has no treatment is defined as the control group. The researchers used experimental research to notice what would happen to the study subject after implementing teaching media as the treatment. In this research, the researchers used an experimental method to investigate using Instagram as a learning media in writing recount text.

The researchers used a Quasi-experimental design, used pre-test, treatment, and post-test. The researchers used this type of method because it does not allow the control and manipulation of all relevant variables. This study deals with two variables, namely Instagram as learning media as the independent variable and writing recount text as the dependent variable. The independent variable is also frequently referred to as the experimental or treatment. The dependent variable refers to the result or outcomes of the study.

The researchers selected X IPS I grade, consisting of 18 students, and X IPS II consisted of 17 students, both as a population and a research sample. As a result, 35 students of both classes at MA Armina Bungkanel, Karanganyar, had a population and sample in this study. Most of the students in this grade have Instagram accounts so that they were familiar with this application.

In collecting the data, the researchers used documentation and pre-test and post-test. Researchers conducted documentation based on data obtained from various sources based on the pre-and post-test sheets, a screenshot of students' text on Instagram and other students' transcriptions. The pre-test and posttest questions comprise two sections, all of which are recount texts. The first part was to create a personal recount text on "Staying at Home during a Pandemic 
Situation" consisting of an orientation, event, and reorientation of at least two pages, consisting of 100150 sentences. While the second part consists of the same mission, at least three paragraphs and the theme was "Holiday Experience" to make writing recount text easy. Besides, the materials also related to talking about students' experiences.

The researchers analyzed data using descriptive quantitative analysis which counts central tendency (mean, median, and mode); dispersion (range, variance) and standard deviation using inferential analysis including normalized n-gain score (n-gain). The formula is as follow:

$$
\text { Normalizedgain }(g)=\frac{\text { Posttest score }- \text { Pretest score }}{\text { Maximum score }- \text { Pretest score }}
$$

\section{Findings}

Aiming to examine whether Instagram as learning media in writing recount text is useful or not, the researchers answered the formulated problems by presenting the pre-test and post-test results descriptively. Besides, the data was also measured using normalized $n$-gain. The descriptive statistics and n-gain scores from both experimental and control groups then were compared to examine the hypothesis.

The highest pre-test score for experimental students was 79 , and the lowest was 58 , with an average score of 69,875 . Whereas the highest post-test score was 90 , the lowest score was 71 . Besides, the result of normality using n-gain in the experimental group was 0.3 . Statistical data of the experiment pretest and post-test outcomes can be seen in table 3.1.

Table 3.1 Descriptive statistic of experimental class result

\begin{tabular}{lll}
\hline Statistic & Pre-test & Post-test \\
\hline Mode & 79 & 85 \\
Median & 69.75 & 79 \\
Mean & 69.875 & 79,46154 \\
Max & 79 & 90 \\
Min & 58 & 71 \\
Range & 21 & 19 \\
Varian & 68,55113636 & 29,26923 \\
St. Dev & 8,279561363 & 5,410105 \\
\hline
\end{tabular}

According to the results, the experimental class students had a significant improvement in their writing tests scores. Instagram was utilized effectively by the teacher to develop students' writing skills. The post-test scores also revealed that all of the students had met the minimum standard score on writing recount text, which is $\geq 70$.

In the control group, the highest pre-test score for students was 73 , and the lowest score was 50 , with an average score of 64,818 . Whereas the highest post-test score was 77, the lowest score was 56. Also, the normality results using the n-gain category in the control class were 0.05 . The statistical data of the control group pre-test and post-test outcomes were summarized in table 3.2 .

Table 3.2 Descriptive statistic of control class results

\begin{tabular}{lll}
\hline Statistic & Pre-test & Post-test \\
\hline Mode & 65 & 62 \\
Median & 65 & 68,5 \\
Mean & 64,81818 & 67,14286 \\
Max & 73 & 77 \\
Min & 50 & 56 \\
Range & 23 & 21 \\
Varian & 44,96364 & 37,20879 \\
St. Dev & 6,705493 & 6,099901 \\
\hline
\end{tabular}

Based on the students' scores in the control group, it meant that there was no significant improvement in the control group. The gap of average scores between pre-test and post-test did not significantly improve. Besides, $35 \%$ of the students in the control group have the scores under the minimum standard score.

\subsection{Hypothesis Testing}

The research hypothesis that used in this research are two kinds of hypothesis; they are:

a) Null Hypothesis $\left(\mathrm{H}_{0}\right)$

The null hypothesis stated that there is no significant effect of using Instagram as a learning media toward students' writing skill.

b) Alternative Hypothesis (Ha)

The alternative hypothesis stated that there is a significant effect of using Instagram as a learning media toward students' writing skill. 

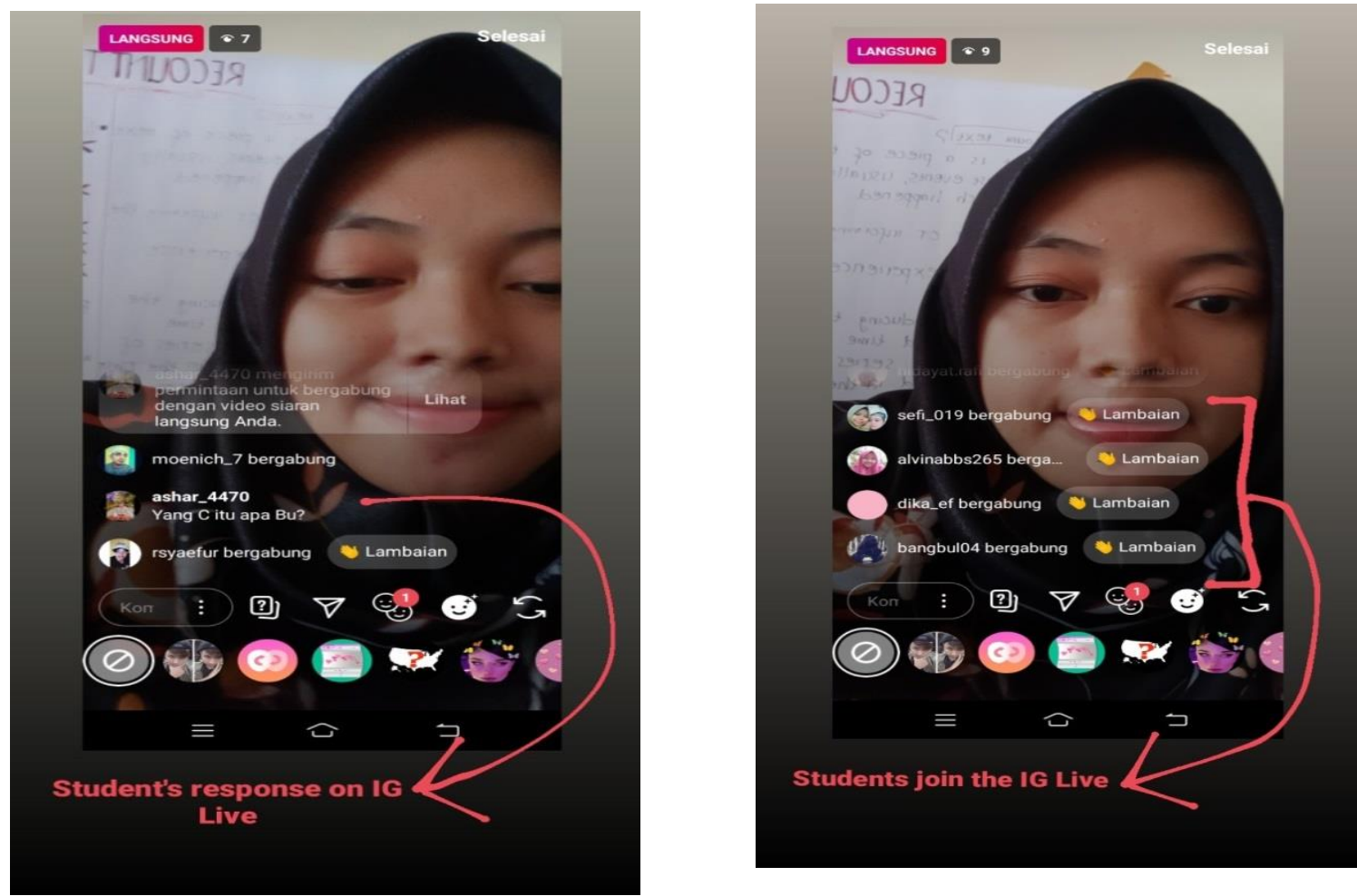

Figure 3.1 Screenshot of Teaching through IG Live

Based on the findings in table 3.1 and table 3.2 , it can be concluded that there was a significant difference in students' writing outcomes between the experimental class and the control class. H0 was rejected, and $\mathrm{Ha}$ was accepted. This fact rejected the null hypothesis, which is said: "there is no significant effect of using Instagram as learning media toward students' writing skill in writing recount text". It accepted the alternative hypothesis, which said, "there is a significant effect of using Instagram as learning media toward students' writing skill in writing recount text".

\section{Discussion}

\subsection{Students' Experiences}

The researchers used Instagram as a learning tool to apply it in various ways according to the needs of students. By incorporating Instagram as a learning media in the English teaching-learning process, students have been encouraged to make the most of it. There have been some learning experiences encountered by students.

\subsubsection{IG Live Features}

The researchers found that many other benefits derived from Instagram, one of the benefits of using Instagram, were IG Live Features, which allowed researchers and students to engage in a single forum. In this forum, the researchers specifically clarified the material without being gathered in the classroom, and the students listened to the material explained by the researchers. Students can also ask the question or answer directly in that forum, and the researchers will answer the students' questions directly in that forum, speak and write on the "comment" part. IG Live can be seen in Figure 3.1.

In this treatment, researchers did an oral presentation about recount text material, such as concept, purpose and social function, general structure, language features of recount text and formula (past tense). Before IG Live began, researchers gave the material through the Instagram Experimental Group, after all the students had read the material, the researchers started IG Live. An oral presentation using live videos, listening to the live presentation, and discussing comments are the activities suggested creating meaningful learning activities using Instagram (Akhiar et al., 2017). Using IG live videos enables the teacher to support face-toface learning with the students while the condition does not let them do traditional formal class. Some researchers claimed that Instagram could support formal learning situations, create an enjoyable classroom atmosphere, and enhance students' communicative skills (Erarslan, 2019; Mansor \& Rahim, 2017). The popularity of Instagram among the young generation can be a useful tool for language learning. The students can get classroom learning atmosphere though live video, shared material, group discussion, and sharing task reports. 

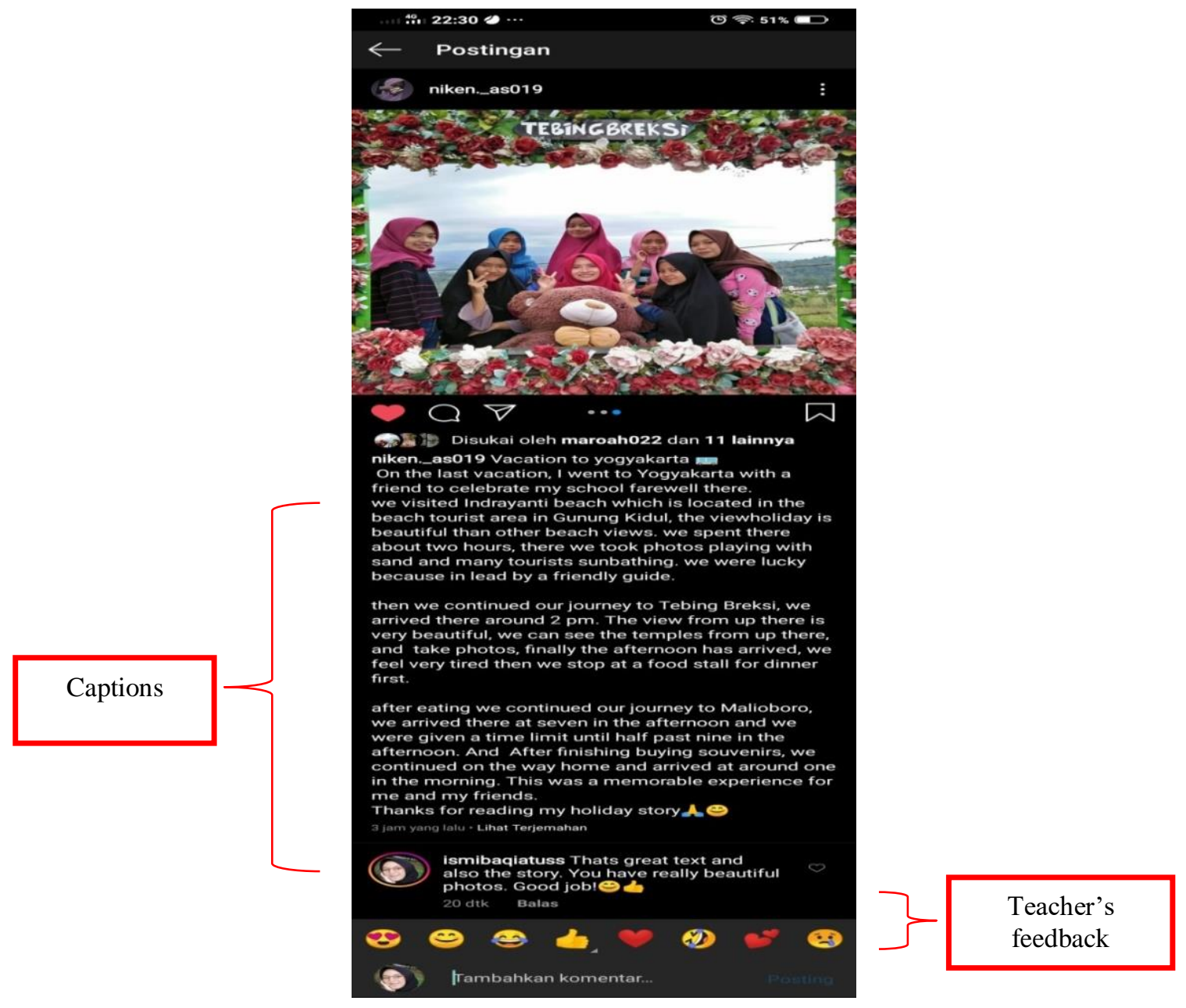

Figure 4.1 Screenshot of Instagram Captions

In the control class, the researchers applied to the classroom (face-to-face learning). In this era of pandemics, due to the Corona virus's spread, face-toface learning must be complemented by strict health protocols. Luckily, MA Armina Bungkanel was part of the green zone. Thus, even though it was only a limit of $50 \%$ of the number of students who took part in learning, it was still possible. According to government guidelines for home learning, using IG Live was a modern way to attract students who could learn from home.

\subsubsection{Instagram Group}

Researchers have set up the Instagram Group; the name of the group is the Experimental Class. The Instagram Group is part of the Instagram features that are appropriate for discussion. In this feature, researchers may have provided material or tasks using photo, video or voice notes. The researchers can explain the material clearly by using a voice note. It can increase students' comprehension of the content even if the learning process is not in the classroom (face to face).

In this treatment, the researchers provided the material via the Instagram group, sent an example of the recount text, and then discussed it with them. Researchers and students will work together to resolve the meaning, social role, linguistics features, and formula found in the text. After that, the researchers provided the students with a problem to solve themselves and sent direct messages to Instagram researchers. Instagram is undeniably a useful tool for student interactions, particularly in the discussion of their work-related activities. The students involved seemed more inspired and loved to participate and connect with their peers, as Instagram fueled their interest in learning (Khalitova \& Gimaletdinova, 2016; Mansor \& Rahim, 2017).

\subsubsection{Corrective Feedback in Instagram Caption}

Instagram provides several tools, such as a filter to entirely edit the image and a caption to explain the images and videos when uploading them (Meisani et al., 2016). The captions in this study were recounting text with images that were suitable for the recount text plot. Students were asked to upload their images in a sequence to retell the story based on the photos they posted. The use of Instagram Caption can be seen in Figure 4.1. 
Students have developed a story about the holiday experience; they should develop a text with excellent images and share it on the Instagram feed. The text should consist of the recount text's general structure, the orientation, event and reorientation of the text. After students post their text, the researchers provided feedback in the "comment" column. The text will be assessed by the researchers and the English teacher based on the organization, the content, the language use, the vocabulary, and mechanics. Writing a caption on Instagram can be a beneficial experience for them to write in English. Writing a caption often gives them exposure as language learners to Englishlanguage functions in a real sense instead of what they say (Meisani et al., 2016). Therefore, the use of Instagram caption could improve students' motivation and writing skill (Akhiar et al., 2017; Gunantar \& Transinata, 2019; Shazali et al., 2019).

Other authors (Soviyah \& Etikaningsih, 2018; Warda \& Wijaya, 2019) also found that the use of Instagram caption could enhance students' writing descriptive text since they can get the ideas to write through the pictures. In writing, having an idea and how to start writing would become a challenge for students whenever they are asked to write (F. Handayani, 2016). Caption on Instagram is useful to be the bridge for connecting the context and writing ideas. The teacher can give useful corrective feedback toward students' post of their recount texts through the comment column. Instagram was indicated as a useful corrective tool to develop students' vocabulary and grammatical accuracy (Shazali et al., 2019).

Students were given a sheet of paper in the control class then created a recount text with the same rules as the experimental class. However, the researchers did not respond because students felt it was difficult and boring to write. Used captions on Instagram in the experimental class, students became more interested and enthusiastic (Mansor \& Rahim, 2017). Besides being equipped with compelling images, Instagram was also equipped with an Instagram-like feature, anyone who likes their text will click the "love" button. This feature will make students more appreciative of their writing. In addition, there is a column of comments that allows other people (followers) to respond to their texts so that students can be peer-reviewers (Nahru, 2020; Sirait \& Marlina, 2018). The peer-review activity may be based on misspelling or grammatical errors. The combination of student outputs and feedback is a crucial element for successful language learning, particularly in writing skills (Aloraini, 2018). The comment column's feature in the Instagram post provides an opportunity for teacher and students to give corrective feedback for improving writing skill. One more thing, in the millennial era, they could be called to up to date person because they uploaded something new on social media, especially on Instagram.

\subsection{The Effectiveness of Instagram as Learning Media in Writing Recount Text}

The researcher compared the post-test score of the experimental class with the control class, the mean score of the post-test in the experimental class was higher than the mean score of the post-test in the control class (79.461 > 67.142). The use of Instagram as a learning media could enhance writing skill (A. D. Handayani et al., 2018; Warda \& Wijaya, 2019) as seen from the students' learning outcomes in control and experimental classes. The researchers used Instagram as a learning media to apply it in various ways, depending on the needs of students. Incorporating Instagram as a learning media in the English teaching-learning process has allowed students to benefit from it.

As shown in table 1 and table 2, the findings indicated that using Instagram as learning media gave a significant improvement in students' writing recount text. There could be several activities in the classroom using Instagram. The students were able to share ideas and views about various topics using this platform. Students may also engage in a group event in which each student could ask the other students to comment on a picture or video that they shared. This allowed them to share information with classmates and teachers. As a website for photo sharing, Instagram could also inspire students to be spatially and linguistically conscious by capturing and editing pictures and the captions and feedback choices (Erarslan, 2019).

The effectiveness of mediating students' writing using Instagram was also reported by Listiani (2016), who compared the treatments of Instagram writing and teacher-centred writing to the students with high and low motivation. On the other hand, Gonulal (2019) found that some students expressed negative attitudes toward Instagram to overcome structurerelated mistakes. Thus, Instagram should not be the only way to learn English informally but should be a platform for learning peripheral languages.

The post-test scores also revealed that all of the experimental group students had reached the standard minimum scores. In contrast, there were $35 \%$ of the control group students have not reached the standard scores. This study has better findings regarding this score improvement than what Gunantar \& Transinata (2019) found in their classroom action research. They found that there were still $3 \%$ of the students who have scores under the standard minimum after employing two classroom action research cycles.

\section{Conclusion}

Instagram, as learning had a significant effect on students' achievement in writing recount text. This present study reveals based on the n-gain in the research findings. The average score of $n$-gain on the experimental class's post-test outcomes was higher 
than an n-gain score of the control class $(0.308><$ 0.05). There was improvement achievement in experimental class than students in the control class. The experimental class's post-test mean score was higher than the post-test mean score of the control class (79.461 $><67.142)$. Therefore, it can be concluded that the students who were taught by using Instagram as learning media have a higher score than those who were taught by conventional ways in writing recount text.

Through the features of Instagram, such as live videos, Instagram group, and caption writing, the students experienced meaningful classroom atmosphere, enjoyable learning activities, peer-review activity, effective corrective feedback, and eventually writing skill improvement. It is suggested that teachers use social media in mediating online learning effectively.

\section{References}

Akhiar, A., Mydin, A. A., \& Adi Kasuma, S. A. (2017). Students' perceptions and attitudes towards the use of Instagram in English language writing. Malaysian Journal of Learning and Instruction (MJLI), Special is, 47-72. https://doi.org/10.32890/mjli.2017.7796

Al-Ali, S. (2014). Embracing the Selfie Craze: Exploring the Possible Use of Instagram as a Language mLearning Tool. Issues and Trends in Educational Technology, 2(2), 1-16. https://doi.org/10.2458/azu_itet_v2i2_ai-ali

Alhabash, S., \& Ma, M. (2017). A Tale of Four Platforms: Motivations and Uses of Facebook, Twitter, Instagram, and Snapchat Among College Students? Social media + Society, 3(1), $1-13$.

https://doi.org/10.1177/2056305117691544

Aloraini, N. (2018). Investigating Instagram as an EFL Learning Tool. Arab World English Journal, 4(4), 174-184. https://doi.org/10.24093/awej/call4.13

Anggraeni, C. W. (2017). Students' Perspectives toward the Use of Instagram in Writing Class. 1st English Language and Literature International Conference (ELLiC), 926-935. https://core.ac.uk/download/pdf/234038172.pdf

Basith, A.-. (2020). Instagram as Media in Teaching Writing Recount Text for Senior High School Students. SALEE: Study of Applied Linguistics and English Education, 1(01), 11-20. https://doi.org/10.35961/salee.v1i01.66

Collin, R. (2012). Genre in Discourse, Discourse in Genre. Journal of Literacy Research, 44(1), 76-96.

https://doi.org/10.1177/1086296X11431627
Damayanti, E., \& Santoso, I. (2019). Students , Perception Towards the Application of Social Media Instagram As an Instructional Media. Professional Journal of English Education, 2(4), 421-428.

Dirgeyasa, I. W. (2016). Genre-Based Approach: What and How to Teach and to Learn Writing. English Language Teaching, 9(9), 45. https://doi.org/10.5539/elt.v9n9p45

Erarslan, A. (2019). Instagram as an Education Platform for EFL Learners. Turkish Online Journal of Educational Technology - TOJET, 18(3), 54-69.

Gonulal, T. (2019). The Use of Instagram as a Mobile-Assisted Language Learning Tool. Contemporary Educational Technology, 10(3), 309-323. https://doi.org/10.30935/cet.590108

Gunantar, D. A., \& Transinata, T. (2019). Writing Caption on Instagram as Media for Student's Motivation and Writing Skill Improvement. ETERNAL (English Teaching Journal), 10(1). https://doi.org/10.26877/eternal.v10i1.3905

Handayani, A. D., Cahyono, B. Y., \& Widiati, U. (2018). The Use of Instagram in the Teaching of EFL Writing: Effect on Writing Ability and Students' Perceptions. Studies in English Language Teaching, 6(2), 112-126. https://doi.org/10.22158/selt.v6n2p112

Handayani, F. (2016). Instagram as a Teaching Tool? Really? Proceedings of the Fourth International Seminar on English Language and Teaching (ISELT-4), 320-327.

Hu, Y., Manikonda, L., \& Kambhampati, S. (2014). What we instagram: A first analysis of instagram photo content and user types. Proceedings of the 8th International Conference on Weblogs and Social Media, ICWSM 2014, 595-598.

Ismail, S., Zaim, M., \& Gistituanti, N. (2018). Teaching Writing by Using Social Media for High School Students in Indonesia. J-SHMIC: Journal of English for Academic, 5(1), 98-112. https://doi.org/10.25299/jshmic.2018.vol5(1).1 160

Khalitova, L., \& Gimaletdinova, G. (2016). Mobile Technologies in Teaching English as a Foreign Language in Higher Education: A Case Study of Using Mobile Application Instagram. ICERI2016 Proceedings, 6155-6161. https://doi.org/10.21125/iceri.2016.0395

Klimova, B. F. (2012). The Importance of Writing. Paripex - Indian Journal Of Research, 2(1), 911. https://doi.org/10.15373/22501991/JAN2013/4 
Linse, C. T., \& Nunan, D. (2005). Practical English Language Teaching: Young Learners. McGraw Hill.

https://books.google.co.id/books?id=d2wvAA AACAAJ

Listiani, G. (2016). The Effectiveness of Instagram Writing Compared to Teacher Centered Writing to Teach Recount Text to Students With High And Low Motivation (The Case of Eight Grade Students in SMP Kesatrian 1 Semarang in the Academic Year of 2015/2016). ELT Forum, 5(1), 1-8. https://doi.org/10.15294/elt.v5i1.9875

Mansor, N., \& Rahim, N. A. (2017). Instagram in esl classroom. Man In India, 97(20), 107-114.

Meisani, D. R., Chofiyya, N. N., \& Handayani, R. (2016). Captions Writing in Instagram: Understanding the Meaning and the Communicative Function in Learning a Language. Jambi-English Language Teaching, 1(2), 90-97.

Mr, E. R., \& Seftika, S. (2019). Instagramas Social Media for Teaching Writing. SMART: Journal of English Language Teaching and Applied Linguistics, 5(1), 60-70. https://doi.org/https://doi.org/10.26638/js.831.2 $03 \mathrm{X}$

Nahru, J. (2020). The Implementation of Peer Feedback Using Instagram in Learning Writing Recount Text for EFL Students at Senior High School Level. RETAIN, 8(3), 43-52.

Richards, J. C. (2015). Key Issues in Language Teaching. Cambridge University Press. https://books.google.co.id/books?id=b6CNCgA AQBAJ

Salikin, H., \& Tahir, S. Z. Bin. (2017). The Social Media-Based Approach in Teaching Writing at Jember University, Indonesia. International Journal of English Linguistics, 7(3), 46. https://doi.org/10.5539/ijel.v7n3p46

Shazali, S. S., Shamsudin, Z. H., \& Yunus, M. M. (2019). Instagram: A Platform to Develop Student's Writing Ability. International Journal of Academic Research in Business and Social Sciences, 9(1). https://doi.org/10.6007/IJARBSS/v9-i1/5365

Sirait, J. B., \& Marlina, L. (2018). Using Instagram As a Tool for Online Peer-Review Activity in Writing Descriptive Text for Senior High School Students. Journal of English Language Teaching, 7(1), 291-301. https://doi.org/https://doi.org/10.24036/jelt.v7i 1.9771
Soviyah, S., \& Etikaningsih, D. R. (2018). Instagram Use To Enhance Ability in Writing Descriptive Texts. Indonesian EFL Journal, 4(2), 32. https://doi.org/10.25134/ieflj.v4i2.1373

Warda, E. G., \& Wijaya, A. (2019). The Effectiveness of Teaching Writing Descriptive Text by Using Social Media "Instagram" to Improve Students' Writing Ability at Junior High School Students. Tell: Teaching of English Language and Literature Journal, 7(1), 16. https://doi.org/10.30651/tell.v7i1.2696 